Universidad de Lima

Facultad de Derecho

Carrera de Derecho

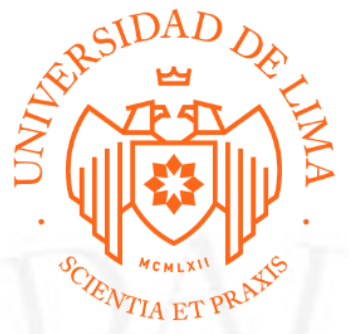

\title{
CIVIL: "DIVORCIO POR CAUSAL" Y ADMINISTRATIVO: "PROTECCIÓN AL CONSUMIDOR"
}

Trabajo de suficiencia profesional para optar el Título Profesional de Abogada

\section{Diana Julissa Arana Solis}

Código 20120091

Lima - Perú

Julio de 2019 


\section{CIVIL: "DIVORCIO POR CAUSAL"}

Materia: Divorcio por causal

$\mathrm{N}^{\mathrm{o}}$ de Expediente: 00193-2008-0-1801-JR-FC-06

\section{RESUMEN}

El presente caso versa sobre temas de Derecho de Familia, en el cual se pretende obtener por parte del demandante, el Señor A. A. A, la disolución del vínculo matrimonial por la causal de separación de hecho y el cese de la obligación alimentaria fijada judicialmente a favor de la demandada, la Señora B. B. B. B., la cual contesta y reconviene, solicitando una indemnización por los daños sufridos. En ese sentido, en el caso se confirman los extremos resueltos relacionados a que, efectivamente, ambos cónyuges cumplen con los elementos que constituyen la causal de separación de hecho y, por ende, se declara disuelto el vínculo matrimonial. Asimismo, se declara la subsistencia de pensión de alimentos a favor de la demandada, por cuanto persiste el estado de necesidad. Por último, en cuanto a la indemnización, la Corte Suprema confirma lo establecido por el juez de primera instancia, vale decir, una indemnización por la suma de 12,000 soles a favor de la demandada, por cuanto considera que es la cónyuge más perjudicada por el divorcio.

\section{"PROTECCIÓN AL CONSUMIDOR"}

Materia: Protección al Consumidor

№ de Expediente: 2306 2012/CPC

\section{RESUMEN}

El presente caso versa sobre el Derecho y Protección al consumidor, en el cual se denuncia por parte del Señor C. C. una falta de idoneidad en el servicio de reparación brindado por D., al no haber reparado correctamente los desperfectos advertidos y que, pese a haberse ofrecido para solucionarlos, no se comunicó con el denunciante para realizar una nueva evaluación al vehículo. Asimismo, se vuelve a denunciar al mismo proveedor por el incumplimiento de una medida correctiva en el plazo fijado por Indecopi, a favor del consumidor. 